\title{
Marine Garbage Dredge Prototype for Coastal Area
}

\author{
Rozeff Pramana ${ }^{1}$, Alena Uperiati $^{2 *}$, Eka Putra Ramdhani ${ }^{3}$, Romi Thomas ${ }^{4}$ \\ ${ }^{1}$ Department of Electrical Engineering, 29100 Maritime Raja Ali Haji University, Indonesia \\ ${ }^{2}$ Department of Informatics Engineering, 29100 Maritime Raja Ali Haji University, Indonesia \\ ${ }^{3}$ Department of Chemistry Education, 29100 Maritime Raja Ali Haji University, Indonesia \\ ${ }^{4}$ Department of Electrical Engineering, 29100 Maritime Raja Ali Haji University, Indonesia
}

\begin{abstract}
Activities carried out in coastal areas such as recreation, fishing activities, and transportation makes coastal regions have an essential role in life. However, activities carried out in the region often leave negative impacts, such as dumping trash directly into the sea. Coastal communities still carry out their activities to dispose of their waste now to the sea. The process of cleaning up marine litter in the coastal areas using heavy equipment is quite tricky. This is because the condition of buildings in the coastal area has the building with the concept of houses on stilts. The research has succeeded in making a marine garbage dredging using a conveyor system that is contained using a wireless joystick and can be well controlled within a radius of about 7 meters. The dredging is also equipped with a weight sensor (load cell) used to determine the load of garbage displayed on the $16 \times 2$ LCD. Garbage weight is stored in the SD card. The data stored on the SD card will show the time and load of garbage that has been transported by conveyor in an area.
\end{abstract}

\section{Introduction}

The coastal area is an area that has an essential function for life. Many activities carried out around coastal regions harm the environment, one of which is throwing garbage directly into the sea. If this activity continues, it will result in environmental pollution, and affect the health of the oceans and have an impact on the lack of fish productivity [1]. Residential buildings in coastal areas are buildings in the form of stilts or platforms that have poles with a distance of $1-1.5$ meters [2].

The house's condition on stilts is complex for heavy equipment to pass through to clean the garbage around the building, and the environmental cleaning process must be done manually. This study aims to design a device that can be controlled to be used as a dredger of marine debris on the surface of the water and can store the amount of garbage transported.

Use A4 paper size $(210 \times 297 \mathrm{~mm})$ and adjust the margins to those shown in Table 1. The final printed area will be 172 × $252 \mathrm{~mm}$.

\section{Literature review}

\subsection{Marine Debris}

Marine debris is a solid material that is produced or processed either directly or indirectly, intentionally or unintentionally, dumped or left into the marine ${ }^{*}$ Environment. Plastic waste in the sea comes from activities and the number of people with a high population [3].

\subsection{Arduino}

Arduino is a hardware device that can be combined with software. Arduino is open-source, so it is easy to use because of the many code libraries and can be used in various operating systems, such as Windows, Macintosh, and Linux. Arduino is available in multiple board modules that use the ATMEL microcontroller as a processor [4].

\subsection{Motor}

A DC motor is a machine that moves and converts electrical energy into mechanical or mechanical energy. A DC motor consists of several main parts, namely a

*Corresponding Author: alenaup@umrah.ac.id 
stationary part (stator) as the motor body or magnetic poles (brushes), and a rotating part (rotor) as a collection of coils or armature windings that produce magnetic flux mounted on the axle [5].

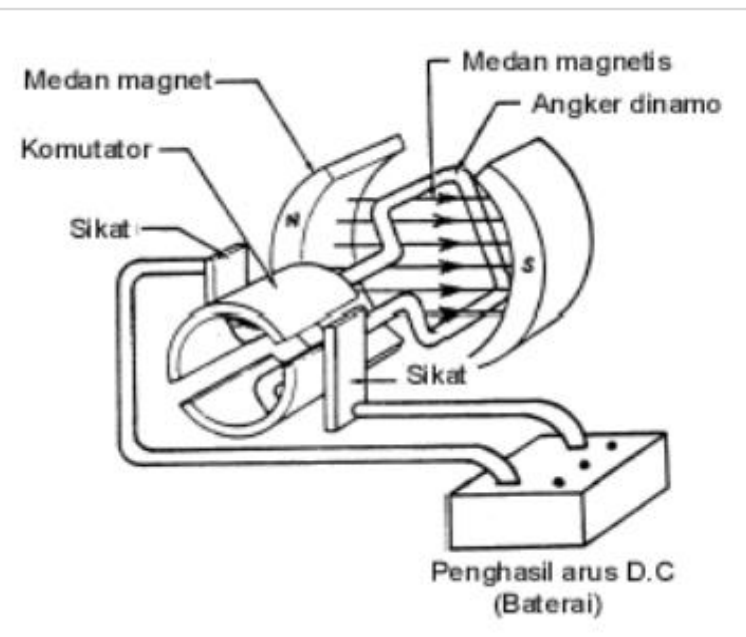

Fig. 1. Simple DC Motor( Source : Irma Wahyuni.,2015)

\subsection{Joystick Playstation PS2 Wireless}

The PS2 Wireless Joystick consists of two modules, namely a transmitter module and a receiver module. The transmitter module functions as input data and sends the input data to the receiver module. In contrast the receiver module acts as a receiver of data sent from the transmitter module. On the PS Joystick (Playstation joystick), there is a controller whose job is to communicate with the Playstation console [6].

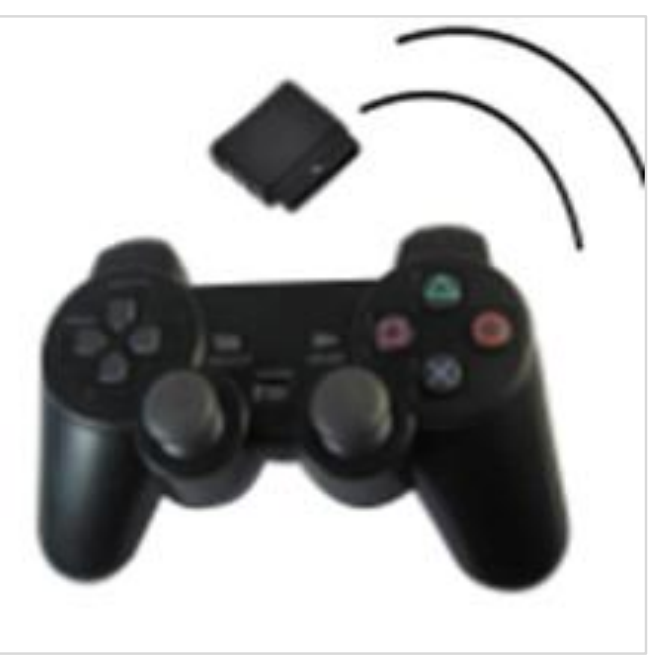

Fig. 2. PS 2 Wireless Joystick (Source: Ekayana, 2017)

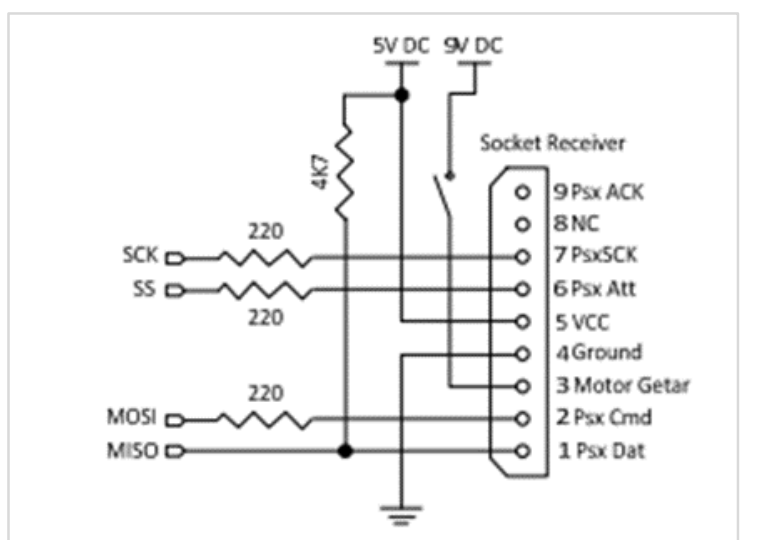

Fig. 3. PS 2 . stick receiver schematic (Source: Zaenurrohman and Sutisna, 2014)

\subsection{Load Cell}

A load cell is a transducer that converts the value of the load, pressure, strain, or force applied to the load cell into an electrical signal by observing the change in resistance by the strain gauge [7].

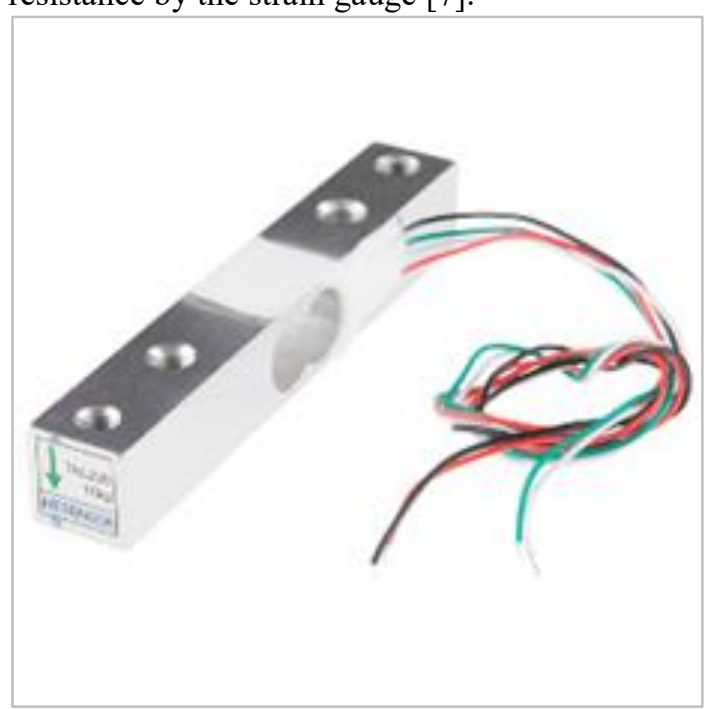

Fig. 4. Load cell $10 \mathrm{Kg}$ (Source: http://www.htcsensor.com/uploadfile/20173211435372654.jpg)

\subsection{Motor Driver VNH2SP30}

The VNH2SP30 motor driver can be used to control motors up to $30 \mathrm{~A}$ and work at a maximum voltage of up to $16 \mathrm{~V}$. This motor driver is also equipped with temperature protection so that the IC can work at high temperatures, as security, it should be added with a heatsink when the current reaches $6 \mathrm{~A}$ as protection against motor drivers [8]. 


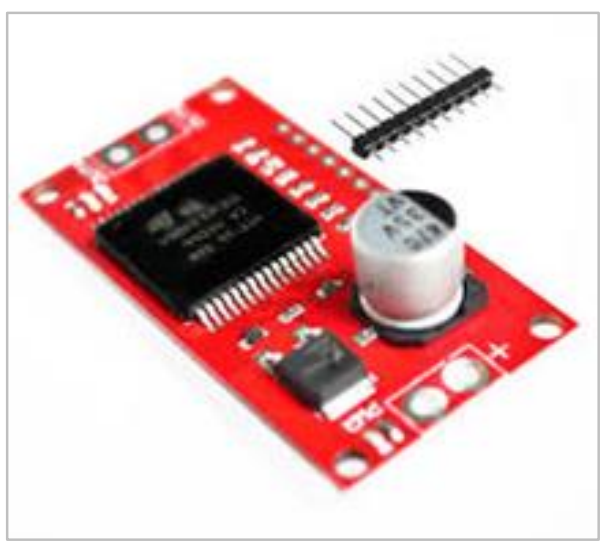

Fig. 5. Motor Driver VHN2SP30 (Source: cdn.instructables.com)

\subsection{Catamaran}

A catamaran is a type of multi-hull vessel that has two hulls (demihull). The catamaran-type ship can lift heavy loads and minimize wobbling on the boat.

In general, the hull of a catamaran consists of three basic shapes, namely:

- The Twinhull model has a symmetrical streamline on both sides of the ship.

- An asymmetrical model of the ship whose outer side is a stream line.

- An asymmetrical ship model with a streamline inside.

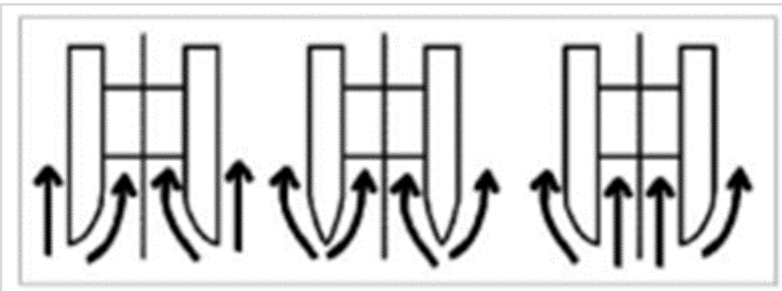

Fig. 6. Hull shape of a catamaran (Source: Alam and Dipo Nugroho, 2018)

The width of the catamaran also creates high ship stability so that it is possible to lift heavy loads from various sides of the boat and the deck area of the ship is more comprehensive than monohull type ships [9].

\subsection{Trash Skimmer Boat}

Trash Skimmer Boat is a pontoon catamaran boat equipped with a conveyor belt with a tub used to collect garbage from the waters through the side of the bow. The conveyor belt is located at the ship's bow and can be lifted and lowered as needed. Garbage is transported by the conveyor belt to the trash bin behind the conveyor belt [10].

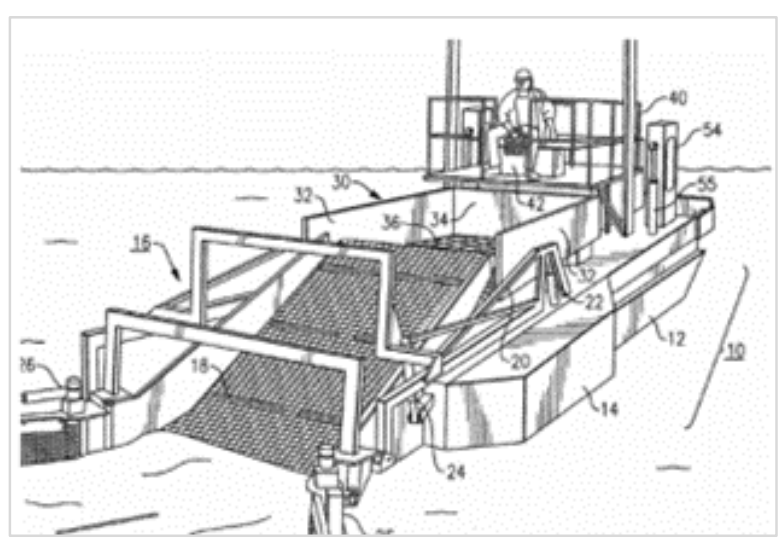

Fig. 7. Trash Skimmer Boat Illustration (Source: Pramoko and Kurniawati, 2013)

\subsection{Chain Transmission}

Transmission on the chain cannot be used for high speeds this is because the chain has a lack of vibration and collisions between chains and friction on the sporket also affects chain resistance [11].

If the correction factor is $\mathrm{f} \mathrm{c}$, then the design power $\mathrm{P} \mathrm{d}$ $(\mathrm{kW})$ as a benchmark is:

$\mathrm{Pd}=\mathrm{fc} . \mathrm{P}(\mathrm{kW}) \quad$ (1)

To calculate chain speed:

$\mathrm{v}=\mathrm{p} . \mathrm{z} \_$(1.) n_1 (2)

Where :

$\mathrm{p}=$ distance for chain $(\mathrm{m})$

z_(1) = number of sprocket teeth

$\mathrm{n} \_1=$ sprocket rotation

Equation (2) is used to calculate the load acting on a circuit $\mathrm{F}(\mathrm{N})$ :

$\mathrm{F}=\left(102 \mathrm{P} \_\mathrm{d}\right) / \mathrm{v}$

Where:

$\mathrm{F}=$ maximum working load/weight $(\mathrm{N})$

P_d = Design Power (Watts)

$\overline{\mathrm{V}}=$ Chain Speed

\section{Research methods}

\subsection{System Design}

\subsubsection{Design of Control System}

The system consists of an Arduino Mega2560 control, joystick wireless, the receiving device receiver, DC motor driver, battery. The control system is used to control the ship's motion and control the rotation of the conveyor. The control system design block can be seen in Figure 8-Block Diagram of Control Device System Design. 


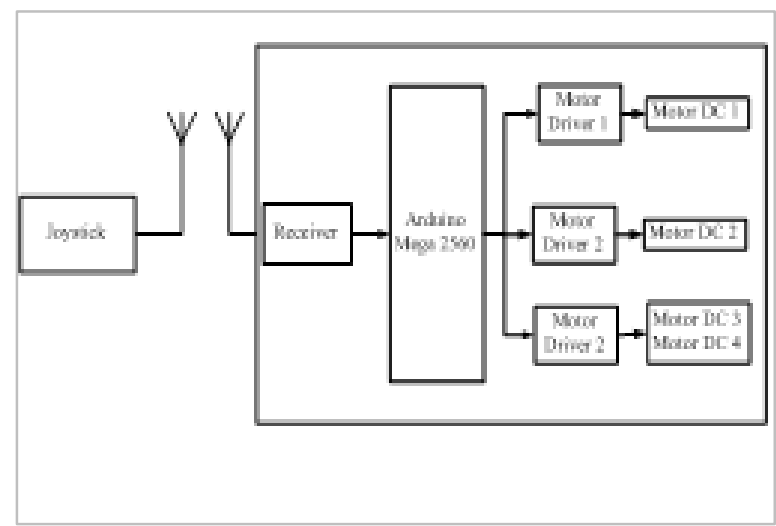

Fig. 8. Control Device System Design Block Diagram

\subsubsection{Weighing and Storage System Design}

The system for weighing and storing waste loads consists of Arduino UNO, load sensor (load cell), 16×2 LCD, RTC (Real Time Clock), and micro SD card module.

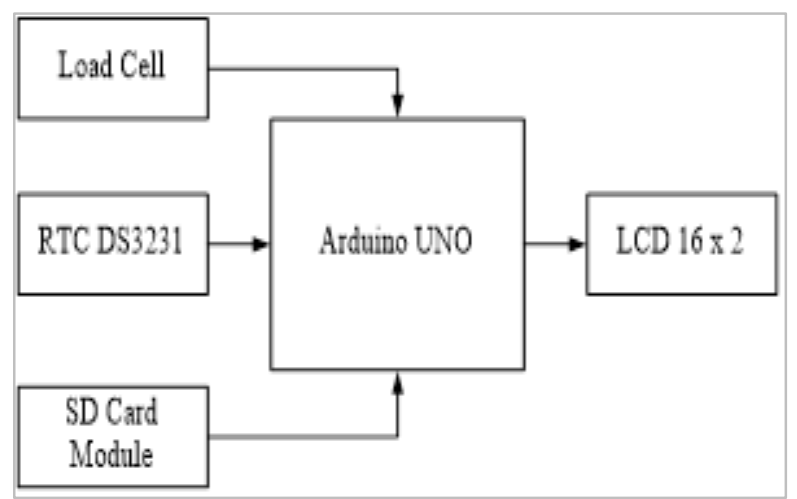

Fig. 9. Block Diagram of Weighing and Waste Load Storage System Design

\subsection{How the Device Works}

\subsubsection{Control System}

Each pushbutton on the Joystick has a command that will control the direction of rotation of the DC motor. The joystick-controlled by the operator will move the device according to the input given to the joystick, namely turning, back and forth, and moving the conveyor. The workings of the control system can be seen in Figure 10.

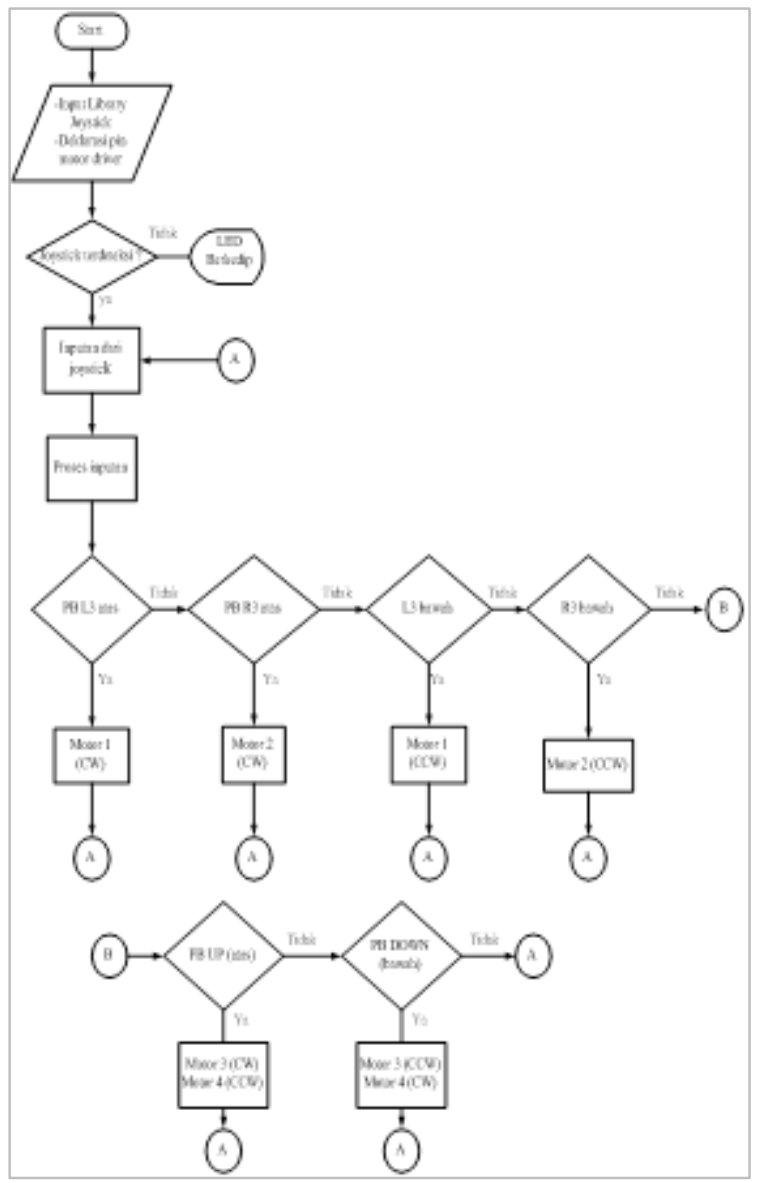

Fig. 10. Control System Flowchart

\subsubsection{Weighing and storage system}

The waste weight will then be displayed as a number on the $16 \times 2 \mathrm{LCD}$, and the waste load will be saved to the SD card along with the time specified on the RTC.

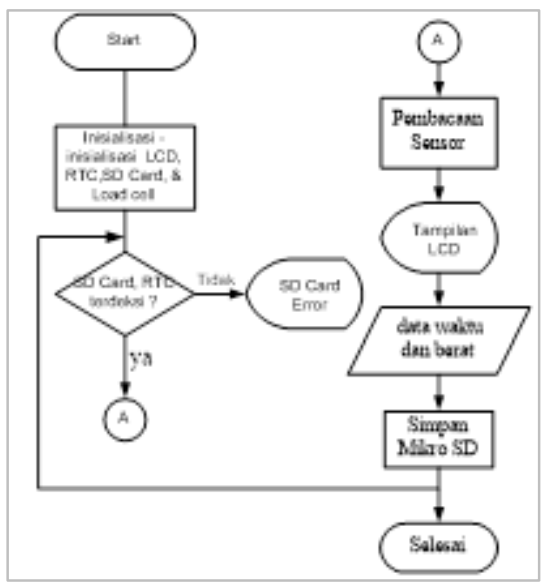

Fig. 11. Flowchart of weighing system and waste weight storage

Garbage weight data will be saved to an SD card in txt format, and storage will be done in one day for one file. 


\subsection{Mechanical Design}

\subsubsection{Ship Design}

Dimensions 1.12 meters long x 0.6 meters and 0.66 meters high.

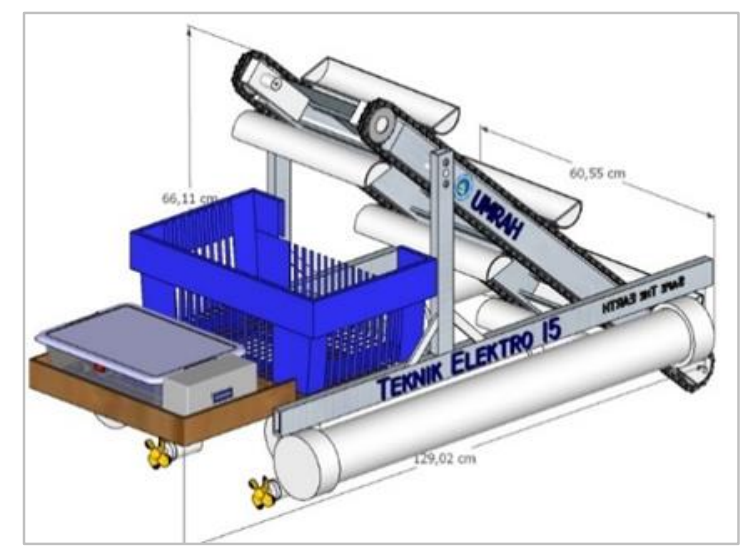

Fig. 12. Ship and Conveyor Design

\subsubsection{Conveyor Design}

The conveyor is made using lightweight aluminum 1.07 meters long and 0.3 meters wide. The scale on the conveyor is made based on the size that has been determined in the ship design. The conveyor is positioned at a 45-degree angle. The rotational speed of the chain on the conveyor can be calculated using equation (1) which aims to determine the ability of the waste scraper on the conveyor.

$\mathrm{v}=(12,7 \mathrm{~mm}) .(16) .(400 \mathrm{rpm})$

$\mathrm{v}=(0,0127 \mathrm{~m}) .(16) .(400 /(60 \mathrm{~s}))$

$\mathrm{v}=1,354 \mathrm{~m} / \mathrm{s}$

Equation (2) is used to determine the load obtained on one chain.

$\mathrm{F}=(102 \mathrm{P} d) / \mathrm{v}$

$\mathrm{F}=((102) \cdot(24$ watt $)) / 1,354$

$\mathrm{F}=1807,9 \mathrm{~N}$

Based on the calculation, the maximum load that can be lifted by one chain is $1807.9 \mathrm{~N}$, and the chain speed is $1.345 \mathrm{~m} / \mathrm{s}$.

\section{System Testing and Analysis}

\subsection{Design Results}

The results of the ship's design with the shape of a catamaran ship are 1.20 meters $x 0.6$ meters long and are added two pieces of 0.5 -meter pipes. The results of the conveyor design are made using lightweight aluminum $2 \times 5$ with a length of 1.07 meters and a width of 0.3 meters.

The conveyor uses a roller chain transmission system. The motor used to rotate the conveyor is a motor for driving a bicycle chain, two $12 \mathrm{~V}, 2 \mathrm{~A}, 400 \mathrm{rpm} \mathrm{DC}$ motors, and a sprocket with 16 teeth. The results of the design can be seen in Figure 13.

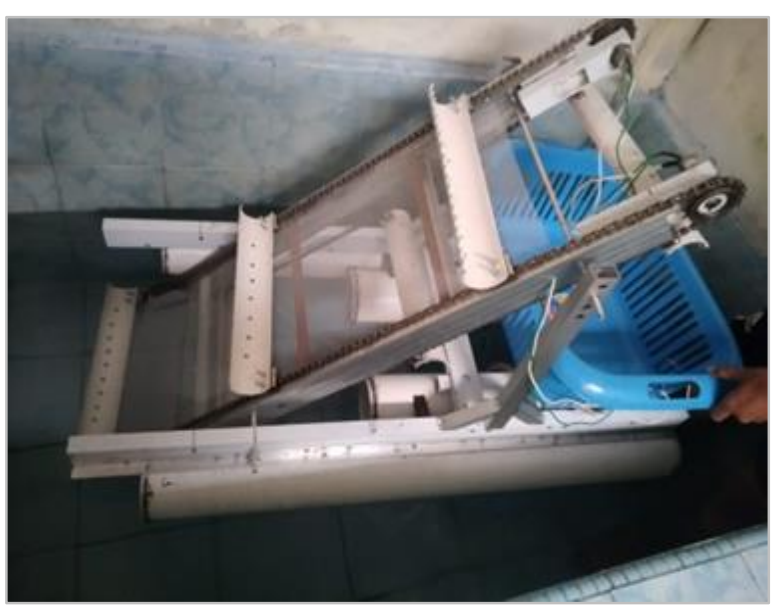

Fig. 13. The results of the design of the garbage scraper

\subsection{Ship Motion Test}

I was testing the ship's motion by providing input on the joystick to move the boat back and forth and turn. The ship motion test was carried out in four trials, starting with a distance of 1-3 meters to the maximum length.

Table 1. Results of testing the ship's motion

\begin{tabular}{|c|c|c|c|c|c|c|c|}
\hline \multirow{2}{*}{$\begin{array}{c}\text { Joystick } \\
\text { button }\end{array}$} & \multicolumn{2}{|c|}{ Motor } & \multirow{2}{*}{$\begin{array}{c}\text { Move } \\
\text { ment } \\
\text { Direct } \\
\text { ion } \\
\end{array}$} & \multicolumn{4}{|c|}{ Distance (m) } \\
\hline & $\begin{array}{c}\text { ka } \\
\text { nan }\end{array}$ & $\begin{array}{l}\text { ki } \\
\text { ri }\end{array}$ & & $1-3$ & $4-5$ & $6-7$ & $8-9$ \\
\hline $\begin{array}{c}R 3 \& L 3 \\
\text { atas }\end{array}$ & $\mathrm{CW}$ & $\begin{array}{l}\mathrm{C} \\
\mathrm{W}\end{array}$ & $\begin{array}{c}\text { Procee } \\
\text { d }\end{array}$ & $\begin{array}{c}\text { Succ } \\
\text { eed }\end{array}$ & $\begin{array}{c}\text { Succ } \\
\text { eed }\end{array}$ & $\begin{array}{c}\text { Succ } \\
\text { eed }\end{array}$ & No \\
\hline $\begin{array}{c}R 3 \& L 3 \\
\text { bawah }\end{array}$ & $\begin{array}{l}\mathrm{CC} \\
\mathrm{W}\end{array}$ & $\begin{array}{l}\mathrm{CC} \\
\mathrm{W}\end{array}$ & $\begin{array}{c}\text { Back } \\
\text { off }\end{array}$ & $\begin{array}{c}\text { Succ } \\
\text { eed }\end{array}$ & $\begin{array}{l}\text { Succ } \\
\text { eed }\end{array}$ & $\begin{array}{c}\text { Succ } \\
\text { eed }\end{array}$ & No \\
\hline L3 atas & - & $\begin{array}{l}\mathrm{C} \\
\mathrm{W} \\
\end{array}$ & Right & $\begin{array}{c}\text { Succ } \\
\text { eed }\end{array}$ & $\begin{array}{c}\text { Succ } \\
\text { eed }\end{array}$ & $\begin{array}{c}\text { Succ } \\
\text { eed }\end{array}$ & No \\
\hline$R 3$ atas & $\mathrm{CW}$ & - & Left & $\begin{array}{c}\text { Succ } \\
\text { eed }\end{array}$ & $\begin{array}{c}\text { Succ } \\
\text { eed }\end{array}$ & $\begin{array}{c}\text { Succ } \\
\text { eed }\end{array}$ & No \\
\hline
\end{tabular}

\subsection{Conveyor Testing}

I am testing the ship's motion by providing input on the joystick to move the conveyor to rotate up and down.

Table 2. Conveyor Testing

\begin{tabular}{|c|c|c|c|c|c|c|c|}
\hline \multirow{2}{*}{$\begin{array}{c}\text { Joys } \\
\text { tick } \\
\text { butt } \\
\text { on }\end{array}$} & \multicolumn{2}{|c|}{ Motor } & $\begin{array}{c}\text { Movem } \\
\text { ent } \\
\text { Directio } \\
\text { nan } \\
\text { an }\end{array}$ & kiri & \multicolumn{4}{|c|}{ Distance (m) } \\
\hline UP & CW & $\begin{array}{c}\text { CC } \\
\text { W }\end{array}$ & Proceed & $\begin{array}{c}\text { Succ } \\
\text { eed }\end{array}$ & $\begin{array}{c}\text { Succ } \\
\text { eed }\end{array}$ & $\begin{array}{c}\text { Succ } \\
\text { eed }\end{array}$ & No \\
\hline $\begin{array}{c}\text { Dow } \\
n\end{array}$ & $\begin{array}{c}\text { CW } \\
\mathrm{W}\end{array}$ & CW & Back off & $\begin{array}{c}\text { Succ } \\
\text { eed }\end{array}$ & $\begin{array}{c}\text { Succ } \\
\text { eed }\end{array}$ & $\begin{array}{c}\text { Succ } \\
\text { eed }\end{array}$ & No \\
\hline
\end{tabular}




\subsection{Weighing and Storage System Testing}

Testing the scales displays the weight on the $16 \times 2$ LCD, and then the importance will be stored in a micro $\mathrm{SD}$. The data is stored in the form (TXT), which will display the time and weight of the garbage.

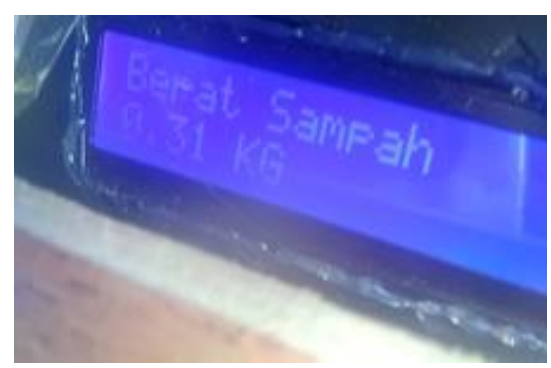

Fig. 14. Garbage weight

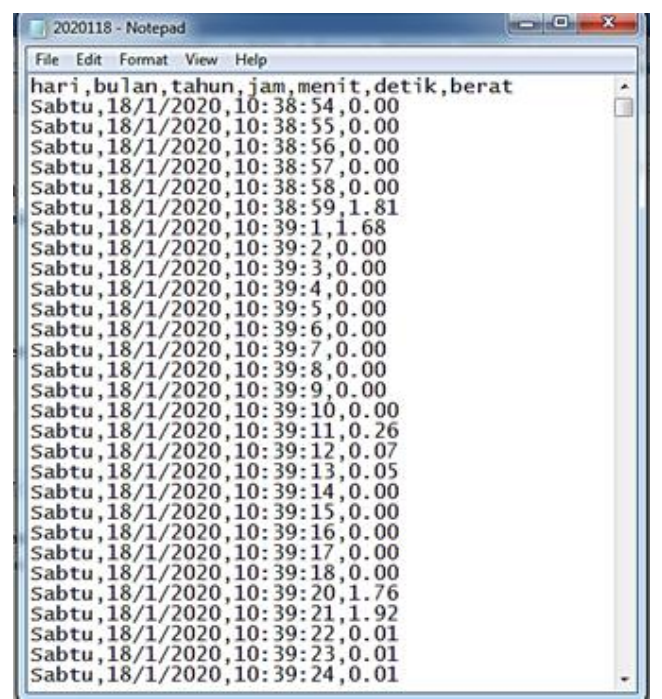

Fig. 15. Show a file that has been saved to the sd card

\subsection{Overall Test}

The overall test begins by controlling the movement in maneuvering (forward, backward, and turning) through the buildings around the research site. Testing the control system on the ship also serves to determine the maximum control distance between the joystick and receiver. The boat can be controlled with a maximum length of 7 meters in open space.

This is also due to the limited distance and weak communication strength of the joystick used. The operator provides input on the joystick and moves the conveyor. The waste is then transported using a conveyor to the trash bin. Garbage lifted using a conveyor is household-scale waste such as plastic drinks, plastic bottles, plastic cups, and bags weighing less than $1 \mathrm{Kg}$.

At the time of testing, the weight of the waste that had been transported into the trash was $1.9 \mathrm{Kg}$. Garbage data and time data obtained from RTC will then be saved to the SD Card. The data that has been stored is used to collect data on the amount of waste that has been removed at a location.

\section{Conclusion}

Based on the purpose of this study, to make a prototype of a marine debris dredger and the results of this study it was found that it can work and operate with a vehicle dimension designed for $1.26 \mathrm{~m} \times 0.6 \mathrm{~m}$ in the form of a rectangle. The device's movement is controlled by a remote controller operated remotely using a joystick by the operator. The movement of the garbage scraper uses two motors that are driven by propellers. The device can be well controlled within a radius of about 7 meters.

The conveyor, that dredges the garbage on the sea surface, is also controlled using a joystick, within a radius of about 7 meters. The device can be operated in tight locations or crevices with limited movement space, such as under houses or coastal buildings, giving it the advantage of cleaning in areas that are difficult to reach by other scrapers or manually.

The capacity of waste that can be transported with this prototype device is $1 \mathrm{~kg}$. The device is equipped with the ability to store data on the waste capacity load that has been carried out by the device and displayed via the LCD. The data is stored on the SD card in (TXT) format.

\section{References}

1. N. Citrasari, N. I. Oktavitri, and N. A. Aniwindira, "Analisis laju timbunan dan komposisi sampah di permukiman pesisir Kenjeran Surabaya," J. Biol. Res., vol. 18, no. 1, pp. 83-85, 2012.

2. S. Listiyanti, Transformasi Rumah Panggung Pada Pemukiman Pesisir Jakarta Utara. 2011.

3. Y. M. Assuyuti, R. B. Zikrillah, M. Arif Tanzil, A. Banata, and P. Utami, "Distribusi dan Jenis Sampah Laut serta Hubungannya terhadap Ekosistem Terumbu Karang Pulau Pramuka, Panggang, Air, dan Kotok Besar di Kepulauan Seribu Jakarta," Maj. Ilm. Biol. Biosf. A Sci. J., vol. 35, no. 2, pp. 91-102, 2018.

4. arduino.cc, "What is Arduino?" [Online]. Available: https://www.arduino.cc/en/guide/introduction. [Accessed: 10-Feb-2019].

5. D. C. Giancoli, Fisika Jilid 2, 5th ed. Jakarta: Erlangga, 2001.

6. Zaenurrohman and U. Sutisna, "Perancangan Sistem Kontrol Wireless pada Mobile Robot Manipulator Berbasis Mikrokontroler ATMega8," J. Nas. Tek. Elektro dan Tekologi Inf., vol. 3, no. 1, pp. 69-75, 2014.

7. N. N. S. S, R. Pramana, and E. Prayetno, "PERANCANGAN PROTIPE KONTROL PENARIK JARING IKAN OTOMATIS,” 2018.

8. STMicroelectronics, "VNH2SP30-E AUTOMOTIVE FULLY INTEGRATED HBRIDGE MOTOR DRIVER,” 2013.

9. H. A. Luhur P, E. S. Hadi, and W. Amiruddin, "Jurnal teknik perkapalan," Tek. Perkapalan, vol. 5, 
no. 2, pp. 421-430, 2017.

10. A. G. Pramoko and H. A. Kurniawati, "Studi Perancangan Trash-Skimmer Boat di Perairan Teluk Jakarta," vol. 2, no. 1, 2013.

11.I. Wahyuni, "Rancang bangun sistem pengangkut sampah pada sungai secara otomatis," 2015. 